Candidates for the US "accelerator of the 90s"

\begin{tabular}{|c|c|c|c|c|}
\hline $\begin{array}{l}\text { Accelerator } \\
\text { CESR II }\end{array}$ & $\begin{array}{l}\text { Institute } \\
\text { Cornell }\end{array}$ & $\begin{array}{l}\text { Collisions } \\
\mathrm{e}+/ \mathrm{e}-\end{array}$ & $\begin{array}{l}\text { Energy } \\
100 \mathrm{GeV}\end{array}$ & $\begin{array}{l}\text { Comments } \\
\text { Would compete with LEP } \\
\text { at higher luminosity }\end{array}$ \\
\hline $\begin{array}{l}\text { CBA } \\
\text { (ISABELLE) }\end{array}$ & Brookhaven & $p / p$ & $800 \mathrm{GeV}$ & $\begin{array}{l}\text { To achieve very high } \\
\text { luminosity for probe } \\
\text { of rare events }\end{array}$ \\
\hline Dedicated collider & Fermilab & $\mathrm{p} / \mathrm{p}, \mathrm{e} / \mathrm{p}$ & $4 \mathrm{TeV}$ & $\begin{array}{l}\text { To extend energy domain } \\
\text { before the end of the } \\
\text { decade to initiate } \mathrm{e} / \mathrm{p} \\
\text { collisions }\end{array}$ \\
\hline "Desertron" & $?$ & $p / p \cdot p / p$ & $20 \mathrm{TeV}$ & $\begin{array}{l}\text { Vastly to extend } \\
\text { energy domain }\end{array}$ \\
\hline
\end{tabular}

$\$ 150$ million, Keyworth said that "this has tobe a time for statesmanśhip, not for pet projects". According to many particle physicists, however, the Department of Energy may be locked into ISABELLE by the need to save face even though the accelerator would be obsolete before it could be completed.

The four projects among which HEPAP will choose were described last week by Leon Lederman, director of Fermilab (see table). He said that the Cornell proposal (CESR II) would be a duplication of LEP, the electron-positron collider being built at CERN in Europe. The machine is not regarded as a major contender, while Lederman also noted that one option for HEPAP is "none of the above".

According to Lederman, there is nevertheless a strong case for going ahead quickly with at least one of these higherenergy machines. He said this was now accepted not only by experimentalists like himself, and one of his slides bore the legend IN THE PAST FIVE YEARS, THE OVERCONFIDENCE OF THEORISTS HAS GIVEN WAY TO PUBLIC CON-

FESSIONS* OF A NEED FOR EXPERIMENTAL GUIDANCE. The accompanying footnote read EXCEPT GLASHOW.

But now even Glashow, Lederman said, has tacitly admitted the need for more experimentation in his somewhat whimsical "oilatron" proposal (see Nature 3 March, p.6). Lederman said that Glashow's "cockamamie scheme" to build an accelerator to search for oil deposits was "just a disguise - he's not interested in finding oil, he just wants the data".

The proposal that Keyworth is said to favour - and his remarks last week backed up this view - is the "desertron", first discussed last summer. It would use "lowtech" magnets and an enormous ring which, presumably, could only be built in the desert in the south-western United States. This machine, with its energy of 20 $\mathrm{TeV}$ per beam, would put the US capability head and shoulders above the "European peril", as Lederman called it, even after CERN's “LEP-prime" (a proton-antiproton collider at $6-10 \mathrm{TeV}$ per beam) is completed, perhaps in 1993.

Stephen Budiansky

\title{
Trust counts bird casualties
}

THE British Trust for Omithology (BTO) this week celebrates $\mathbf{5 0}$ years of monitoring bird populations in the British Isles. The trust's surveys, which are widely respected, are based on information collated from reports sent in by volunteers all over Britain. That they have gained scientific respectability makes a pleasing illustration of the very useful role that amateurs can still play in serious research.

At the trust's headquarters in Tring, Hertfordshire, a small professional staff funded langely by the Nature Conservancy Council coordinates the two main threads of BTO's work. These are the Common Binds Census, which monitors population levels on the basis of amateurs' sightings, and the National Ringing Scheme, which gathers information on mortality and migration patterns. In addition the trust publishes occasional detailed surveys on particular species, and has undertaken studies for the EEC and for BP Petroleum Development Ltd on the effects of oil spills on seabirds. Prompt information from BTO on the effects on bird

\section{IMAGE \\ UNAVAILABLE FOR COPYRIGHT REASONS}

W.S. Paton/RSPB

BTO figures showed that massive numbers of razorbills, puffins and guillemots were killed off the east coast of Britain in storms during February. populations of the severe winter of 1981-82 was influential in bringing about a temporary ban on the shooting of wildfowl while populations recovered. The trust gains significant revenues from sales of its various publications, and is now seeking sponsorship for a Winter Atlas of distribution of birds in Britain.

Tim Beardsley
US nuclear physics

Argonne's loss

Meanwhile, Argonne National Laboratory lost the first round in its bid to build a new $4 \mathrm{GeV}$ electron accelerator last week when a panel of the Nuclear Science Advisory Committee (NSAC) endorsed a competing proposal submitted by a consortium of 20 south-eastern universities (see Nature 17 March, p.204). Although a final decision need not be made until next January, when the budget for 1984-85 is drawn up, NSAC's recommendations have usually carried weight.

The panel's recommendation came as an especially severe blow to Argonne which had been hanging its hopes on the electron accelerator in its effort to regain lost prestige in basic nuclear physics. Argonne director Walter Massey appeared before NSAC last Friday to offer a polite but vigorous dissent from the panel's report.

Massey argued that on purely technical grounds of cost effectiveness, support facilities and staff expertise, Argonne had the edge on the Southeastern Universities Research Association (SURA). And he took exception to the emphasis the panel appeared to place on SURA's pledge to create 35 new tenured faculty positions in nuclear physics if its proposal were approved. Massey noted that this was a policy matter, not a technical matter, and further that "if this is to be a determining factor, then $I$ am convinced that we, in the Midwest, can also respond" with university faculty positions. He said soundings of the University of Chicago and the University of Illinois were favourable.

Massey asked the committee to forward the report to the Department of Energy (DoE) without an endorsement, so that "the institutional and policy questions can be discussed and debated within the proper framework, which has to be at the Department level". Unstated was the likelihood that Argonne may have more influence at that level than SURA.

The SURA proposal calls for an electron accelerator with an energy range of $0.5-4$ $\mathrm{GeV}$, to be built in Newport News, Virginia. The panel noted the flexibility that SURA's design offers in being able to expand to $6 \mathrm{GeV}$ (while admitting that there is as yet no justification for going to these higher energies) and SURA's more "conservative" design that some panel members felt was less susceptible to stability problems than Argonne's.

But the panel at the same time expressed some reservations about the SURA proposal, most notably the remoteness of the proposed site from a major university and from an international airport.

NSAC appears ready to forward the panel's report, but may raise some questions in a letter to accompany it. The final outcome is not likely to be settled until DoE makes its budget recommendations, months from now.

Stephen Budiansky 